Volume 1, Nomor 2, Oktober 2020, 41-53

JTTM: Jurnal Terapan Teknik Mesin

p ISSN 2721-5377| e ISSN 2721-7825

\title{
PERANCANGAN MESIN PENGIRIS SINGKONG
}

\section{DESIGN OF THE SINGLE SLIVER MACHINE}

\author{
Asep Yandi ${ }^{1}$, Firmansyah Azharul ${ }^{2 *}$, Veriah Hadi ${ }^{3}$ \\ 1,2* Program Studi Teknik Mesin, Sekolah Tinggi Teknologi Muhammadiyah Cileungsi \\ $1,2^{*}$ Jl. Anggrek, No 25, Komplek PT.SC, Cileungsi, Bogor, Jawa Barat 16820 \\ ${ }^{3}$ Program Studi Fisika, Institut Sains dan Teknologi Nasional, Jakarta, Indonesia \\ ${ }^{3}$ Jl. Moh. Kahfi II, Bhumi Srengseng Indah, Jagakarsa, Jakarta Selatan, Indonesia 12640 \\ *Koresponden Email: firmansyah.azharul@sttmcileungsi.ac.id
}

\begin{abstract}
Abstrak. Singkong sering dimanfaatkan sebagai bahan makanan ringan oleh masyarakat luas. Kelemahannya, singkong akan mudah membusuk jika tidak segera diolah sehingga banyak yang terbuang percuma. Untuk itu perlu dilakukan pengolahan pasca panen dengan baik. Salah satu proses pengolahannya adalah dengan membuat keripik singkong. Usaha ini banyak dikerjakan di rumah-rumah sebagai home industry. Permasalahan yang sering dihadapi berupa kualitas produk yang kurang baik karena ukuran potongan yang bervariasi serta produktivitas yang rendah. Tujuan penelitian ini untuk merancang alat pengiris singkong dengan kapasitas yang cukup dan memiliki ketebalan hasil irisan yang seragaman. Metode yang dilakukan dengan studi literatur dan proses perancangan. Hasil dari penelitian ini berupa mesin pengiris singkong yang mempunyai kapasitas produksi $90 \mathrm{Kg} / \mathrm{jam}$ dengan hasil irisan yang seragam.
\end{abstract}

Kata Kunci: Singkong, Pengiris Singkong, Kualitas, Produktivitas

Abstract. Cassava is often used as a snack ingredient by the community. The drawback is that Cassava will rot easily if it's not processed immediately. As a result, cassava can be wasted. For this reason, cassava processing is necessary. One of the processing of cassava that is commonly done as a business is making cassava chips. This business is mostly done in homes as a home industry. The problems that are often faced are in the form of poor product quality due to the variety of cut size and low productivity. The purpose of this study was to design a cassava slicer with sufficient capacity and uniformity in terms of the thickness of the slices. The method used is by means of a literature study and design process. The results of this study were cassava slicing machines that had a production capacity of $90 \mathrm{~kg} / \mathrm{hour}$ with uniform slices.

Keywords: Cassava, Cassava slicer, quality, productivity.

\section{PENDAHULUAN}

Bidang agribisnis merupakan primadona baru bagi masyarakat Indonesia sebagai ladang usaha. Sayangnya, proses produksi agribisnis kebanyakan masih menggunakan peralatan tradisional. Inilah yang membuat bidang agribisnis sulit untuk bisa bersaing dengan industri pengolahan lainnya. Nilai tambah yang diciptakan oleh Usaha Kecil Menengah (UKM) di bidang agribisnis masih relatif rendah [1]. 
Singkong merupakan komoditas hasil pertanian, sumber karbohidrat yang penting setelah beras. Seiring dengan perkembangan teknologi, singkong tidak hanya dimanfaatkan sebagai makanan saja tetapi juga dimanfaatkan sebagai bahan baku industri [2]. Singkong merupakan tumbuhan perdu tropis yang banyak dimanfaatkan sebagai bahan makanan terutama bagian akar dan juga daunnya [3].

Singkong merupakan salah satu tanaman utama yang diproduksi di Indonesia. Singkong tumbuh di seluruh provinsi di Indonesia. Dalam satu dekade terakhir, meskipun luas areal perkebunan ubi kayu menurun, produksi dan produktivitas ubi kayu di Indonesia terus mengalami peningkatan [4]. Tanaman ini termasuk famili Euphorbiaceae yang mudah tumbuh sekalipun pada tanah kering dan miskin serta tahan terhadap serangan penyakit maupun tumbuhan pengganggu (gulma). Tanaman singkong mudah membudidayakannya, karena perbanyakan tanaman ini umumnya dengan stek batang [5].

Singkong atau ubi kayu (Manihot esculenta Crantz) merupakan salah satu sumber karbohidrat lokal Indonesia yang menduduki urutan ketiga terbesar setelah padi dan jagung [6]. Kelemahannya, singkong mudah membusuk dalam jangka waktu 2 sampai 3 hari setelah panen, bila tidak mendapatkan perlakuan pasca panen dengan baik. Akibatnya singkong bisa terbuang percuma. Untuk itu perlu dilakukan pengolahan singkong. Tujuan pengolahan ubi kayu (singkong) adalah untuk meningkatkan keawetan ubi kayu sehingga layak untuk dikonsumsi dan memperoleh nilai jual yang tinggi dipasaran [7].

Salah satu pengolahan singkong yang umum dilakukan sebagai usaha adalah membuat keripik singkong. Usaha ini banyak dikerjakan di rumah - rumah sebagai home industry. Masalah yang dihadapi dalam usaha ini ternyata tidak sedikit, sehingga harapan untuk mendapat penghasilan lebih tidak tercapai.[8] Sebagaimana agroindustri lainnya, salah satu masalah yang dihadapi adalah pemasaran. Hal ini karena kualitas produk yang kurang baik [9]. Di antara kekurangan produk keripik singkong home industry adalah ukuran potongan yang tidak standar.

Atas dasar itulah dirasa perlu untuk diadakan penelitian untuk merancang alat pengiris singkong dengan kapasitas yang cukup dan memiliki keseragaman dalam hal ketebalan hasil irisan.

\section{METODE}

Metode yang digunakan dalam melaksanakan penelitian.

A. Studi literatur (kajian pustaka) merupakan penelusuran literatur yang bersumber dari buku, media, pakar ataupun dari hasil penelitian orang lain. Kajian teori merupakan salah satu tahapan dalam penelitian yang harus dilakukan.Penyusunan kajian teori menjadi dasar pertimbangan dalam penentuan langkah-langkah penelitian [10]. Dalam hal ini kajian pustaka difokuskan pada dasar teori yang berkaitan dengan mengenai mesin pengiris singkong dengan sistem otomatis.

B. Perancangan mesin pengiris singkong dilakukan berdasarkan hasil studi literatur yang telah dilakukan. Secara sederhana proses perancangan yang dilakukan terlihat seperti diagram alir di pada gambar 1 . 

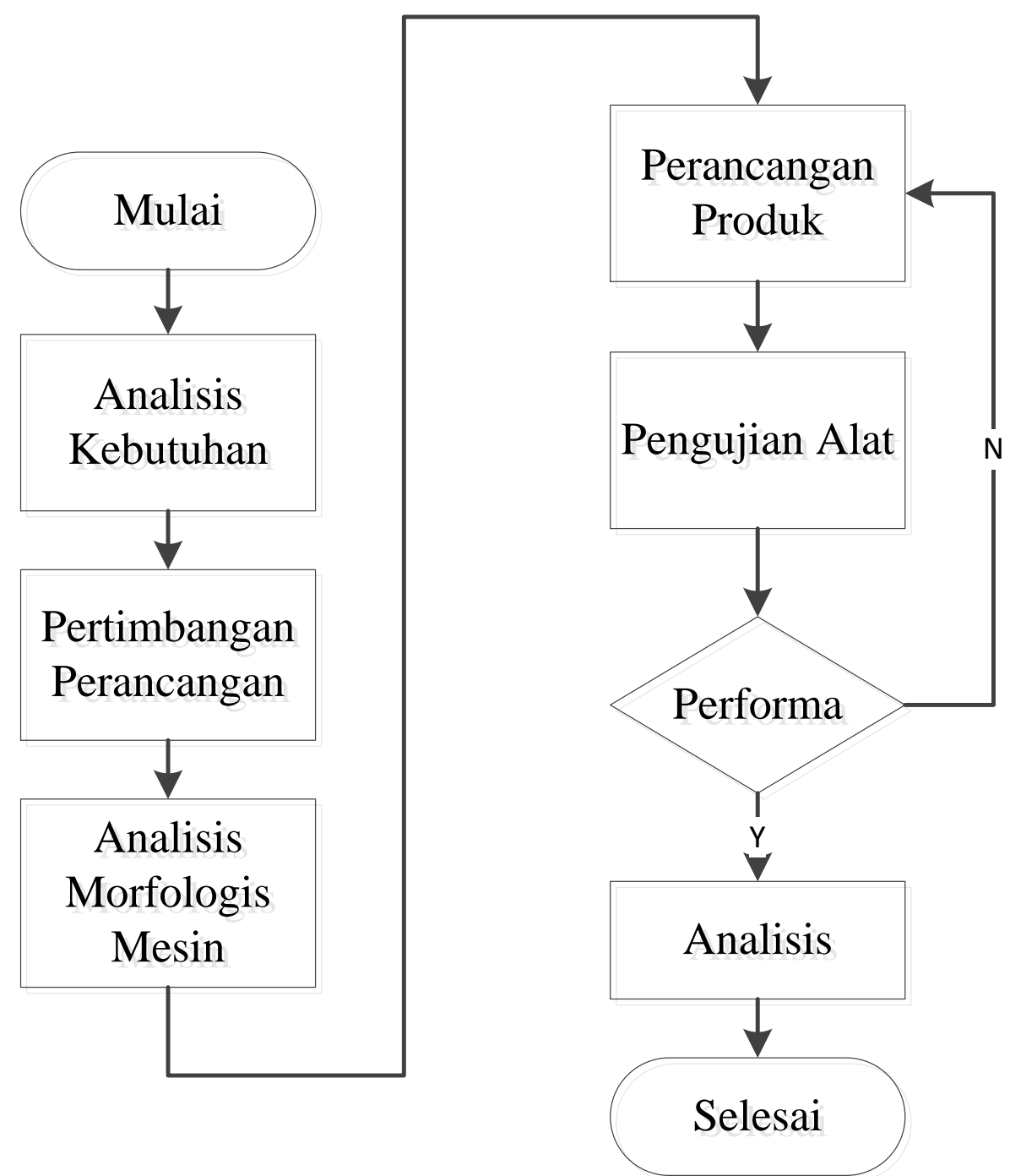

Gambar 1. Diagram alir perancangan.

\section{HASIL DAN PEMBAHASAN}

\subsection{Analisis Kebutuhan.}

Langkah-langkah analisis kebutuhan perancangan mesin pengiris singkong dilakukan sesuai dengan metode yang dilakukan.

A. Pernyataan.

Dibutuhkan mesin pengiris singkong produktivitas tinggi dan harga mesin yang terjangkau untuk pengusaha kelas menengah ke bawah atau industri rumahan.

B. Spesifikasi Tenaga Penggerak.

Tenaga penggerak yang digunakan tidak lagi menggunakan tenaga manusia, melainkan dengan menggunakan tenaga penggerak lain.

C. Spesifikasi Pergeseran Singkong pada Dudukan pisau. 
Untuk mendorong singkong pada dudukan pisau, mesin pengiris singkong ini tidak menggunakan tenaga manusia melainkan dengan menggunakan pegas.

D. Standar Penampilan.

Konstruksi mesin pengiris singkong ini telah disesuaikan dengan kenyamanan, keamanan, dan kemudahan dalam pengoperasian. Dimensi alat tidak cukup besar, sehingga mesin ini dapat dengan mudah dipindah-pindah.

E. Target Keunggulan produk.

Target atau sasaran yang ingin dicapai dari perancangan.

- Proses pembuatan dapat dikerjakan dengan mudah dan cepat.

- Material alat mudah dicari.

- Alat mampu meningkatkan kualitas hasil produksi.

- Hasil pengirisan dapat seragam.

- Perawatan dan pemeliharaan mudah dilakukan.

○ Mudah dalam pengoperasian.

3.2 Pertimbangan Perancangan.

Berdasarkan uraian analisis kebutuhan diatas maka pertimbangan perancangan yang dilakukan pada mesin pengiris singkong.

A. Pertimbangan material.

Material mudah didapat dan harganya murah, sesuai dengan standar umum, memiliki umur pakai yang panjang serta memiliki sifat mekanis yang baik.

B. Pertimbangan Ergonomi.

Pertimbangan ergonomi, nyaman saat dioperasikan, mudah dipindahkan, dan mudah dioperasikan.

C. Pertimbangan Produksi.

Alat dapat diproduksi oleh bengkel kecil, suku cadang mudah didapat dan murah. Pemakai tidak memerlukan perawatan yang sulit untuk merawat mesin ini.

D. Pertimbangan Lingkungan.

Alat didesain agar tidak menimbulkan pencemaran udara, alat dirancang supaya tidak menimbulkan suara yang bising.

E. Pertimbangan Keselamatan Kerja.

Alat ini tidak mengaplikasikan bahan yang berbahaya bagi keselamatan. Konstruksi alat didesain sesuai dengan posisi kerja yang aman dan nyaman, sehingga keselamatan bisa terjamin.

3.3 Analisis Morfologis Mesin Pengiris Singkong. 
Berdasarkan data diatas maka didapat gambaran komponen yang akan membentuk mesin pengiris singkong yang sedang dirancang. Dengan demikian maka dapat disusun suatu skema klasifikasi yang disebut matriks seperti terlihat dalam tabel 1 .

Tabel 1. Matriks morfologis mesin pengiris singkong

\begin{tabular}{|c|c|c|c|c|}
\hline \multirow[t]{2}{*}{ No } & \multirow[t]{2}{*}{ Sub komponen } & \multicolumn{3}{|c|}{ Komponen yang digunakan } \\
\hline & & 1 & 2 & 3 \\
\hline 1 & $\begin{array}{l}\text { Protit rangkea } \\
\text { mesin }\end{array}$ & & Profil Kotak & Pion \\
\hline 2 & Pengegeralk & tor 1 , & Motor ligtrik. & \\
\hline 3 & Sistem transmisi & Rantai & Pulu \& $\mathrm{V}$-Beit & \\
\hline 4 & Pisau & Pisau Alur tengah & Pisan kotak & \\
\hline s & $\begin{array}{l}\text { Sistem putaran } \\
\text { Pisau }\end{array}$ & Putaran vertical & $\begin{array}{c}\text { U } \\
\text { Putaran } \\
\text { Horizontal }\end{array}$ & \\
\hline
\end{tabular}

\subsection{Perancangan Mesin Pengiris Singkong.}

Perancangan ini dibutuhkan beberapa komponen untuk bisa dioperasikan. Adapun komponen pendukung.

A. Motor.

Untuk menggerakan pisau pemotong singkong menggunakan motor listrik dengan kapasitas $1 / 2 \mathrm{Hp}$.

$\mathrm{P}=1 / 2 \mathrm{Hp}$.

$\mathrm{N}=1400 \mathrm{rpm}$.

Tegangan $=110 / 240$ volt.

B. Poros

Poros ini untuk menghubungkan Puli dengan roda penggerak yang menggunakan listrik maupun manual (engkol). Adapun $V$-belt untuk menggerakan pisau pemotong singkong.

Poros mesin pemotong yang dibuat mempunyai panjang 310mm yang ditopang oleh 2 buah bearing.

Setelah menganalisa jarak poros selanjutnya perlu menghitung perencanaan poros mesin pengiris singkong. $\mathrm{P}=0.5 \mathrm{Hp}=0,372849 \mathrm{kw}, \mathrm{n}=180 \mathrm{Rpm}, \mathrm{fc}=1.2$

Daya yang ditransmisikan. 
- $\mathrm{P}=0.5 \mathrm{Hp}$

$=0.372849 \mathrm{~kW}$

- Putaran poros.

$$
\mathrm{n}=180 \mathrm{rpm}
$$

Torsi yang dihasilkan.

$$
\begin{aligned}
\mathrm{T} & =\frac{P .72658,1}{n} \\
& =150 \mathrm{Kg} / \mathrm{cm} \sim 1500 \mathrm{Kg} / \mathrm{mm}
\end{aligned}
$$

Tegangan geser yang timbul.

$$
\begin{aligned}
& \tau=\frac{5,1 T}{d s^{3}} \\
& =\frac{5,1 \cdot 1500}{21^{3}} \\
& =0,826 \mathrm{~kg} / \mathrm{mm}^{2}
\end{aligned}
$$

Sebagai keamanan awal maka faktor koreksi diambil lebih kecil.

$$
\mathrm{fc}=1.2
$$

Adapun dalam perhitungan poros didapat nilai.

$\mathrm{Pd}=\mathrm{fc} \times \mathrm{p}$

$=0.447418$

Momen puntir rencana

$$
\begin{aligned}
& \mathrm{Pd}=0.447418 \\
& \mathrm{n}=180 \\
& \mathrm{~T}=9.74 \times 10^{5} \frac{\mathrm{pd}}{\mathrm{n}} \\
& =9.74 \times 248.5=2420,39 \mathrm{~kg} / \mathrm{mm}
\end{aligned}
$$

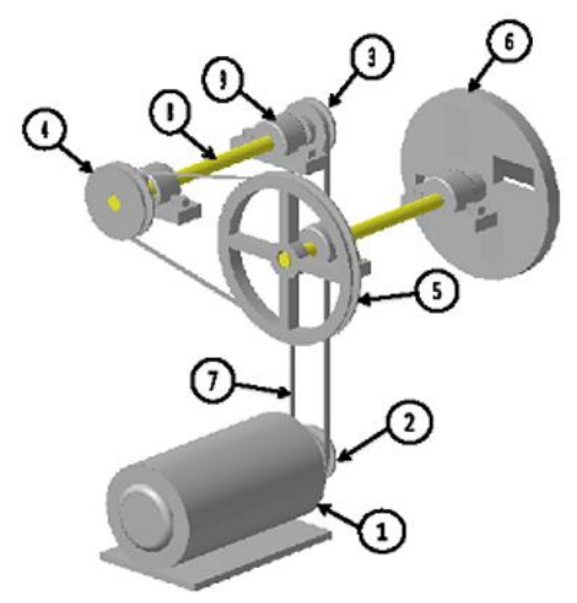

Gambar 2. Mesin Pengiris Singkong 
Pada gambar 2 dijelaskan, 1) Motor listrik, 2) Pulley motor listrik, 3) Pulley poros tengah, 4) Pulley poros tengah, 5) Pulley dudukan pisau, 6) Dudukan pisau, 7) V-Belt, 8) Poros, 9) Dudukan bearing.

Material poros yang dipergunakan untuk memotong singkong ST37, kekuatan tarik $\sigma_{\mathrm{B}}=37$ $\mathrm{kg} / \mathrm{mm}^{2}$. Dalam perhitungan $s f 1$ dan $s f 2$ dengan batas kelelahan puntir $s f 1=6$ dan $s f 2=2$, karena dipertimbangkan pengaruh kekasaran permukaan material.

a. Tegangan geser

$$
\tau_{\mathrm{g}}=\frac{\sigma \mathrm{B}}{s f 1 . s f 2}=3 \mathrm{~kg} / \mathrm{mm}^{2}
$$

b. Faktor Koreksi Puntiran dan Lenturan.

Momen puntir jika beban dikenakan dengan kejutan besar $k_{\mathrm{t}}=1.5-3.0$ maka diambil $k_{t}=1,5$

Momen lentur dinyatakan $k_{m}$ dengan harga 1.5-3.0. Faktor tersebut ditinjau apakah poros berputar dengan pembebanan momen lentur yang tetap, mengalami tumbukan ringan atau mengalami tumbukan berat. Berdasarkan pertimbangan yang diperhitungkan alat pemotong singkong menggunakan $k_{m}=3,0$ karena mengalami tumbukan berat.

c. Diameter Poros

$$
\begin{aligned}
& \mathrm{d}_{\mathrm{s}}=\left[\frac{5.1}{\tau g} \mathrm{k}_{\mathrm{t}} \cdot \mathrm{k}_{\mathrm{m} \cdot} \cdot \mathrm{T}_{\mathrm{g}]}^{1 / 3}\right. \\
& \mathrm{d}_{\mathrm{s}}=21.267 \mathrm{~cm} \sim 21 \mathrm{~cm}
\end{aligned}
$$

\subsection{Transmisi Pulley dan Sabuk V (V-Belt).}

Mesin pemotong singkong ini terdiri dari beberapa transmisi yaitu puli, sabuk vee belt, poros, serta motor listrik.

Cara penggerak sistem transmisi, dimulai dari puli 1, menggerakan ke puli 2.3, dan 4 dengan menggunakan v belt, dan selanjutnya ditransmisikan ke poros, poros disini akan memutarkan dudukan pisau, untuk mengiris singkong. Rangkaian sistem transmisi sabuk V ( $V$-belt)

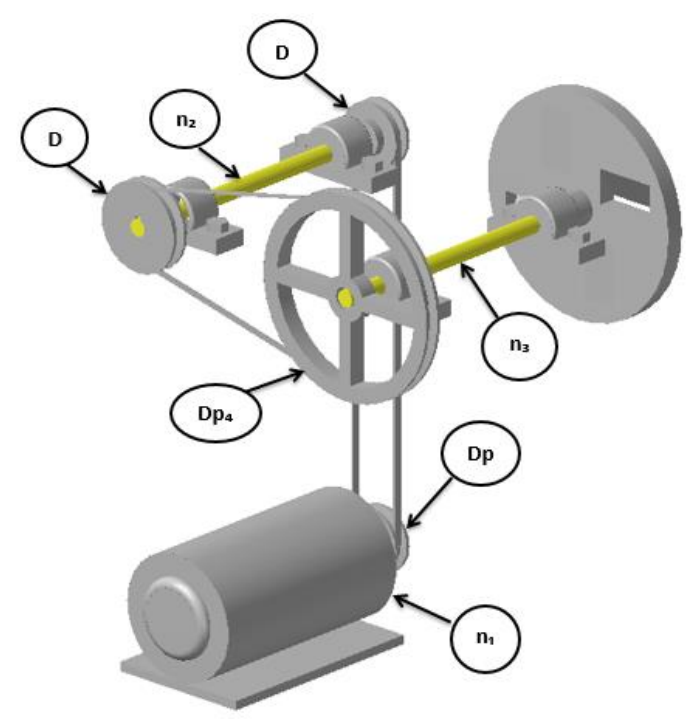

Gambar 4. Diagram alir perancangan $V$-Belt 


\subsection{Pulley dan Sabuk V (V-Belt)}

Untuk mereduksi putaran dari $\mathrm{n}_{1}=1400 \mathrm{rpm}$ menjadi $\mathrm{n}_{3}=462 \mathrm{rpm}$. Alat pemotong singkong ini mempunyai variasi beban yang diperkirakan selama bekerja 4-5 setiap hari dan dengan waktu koreksi 1,5 .

a. Perhitungan perancangan poros

1. $\mathrm{p}=1 / 2 \mathrm{HP}$

$\mathrm{Pd}=\mathrm{fc} \times \mathrm{P}=0.55927$

2. $\mathrm{T}=9,74 \times 1 \mathrm{C}^{5} \frac{\mathrm{pd}}{\mathrm{n}}=3019,4 \mathrm{~kg} / \mathrm{mm}$

b. Penampang V-belt yang digunakan : Tipe A

c. Diameter pulley

$$
\begin{aligned}
& \mathrm{d}_{\mathrm{p} 1}=75 \mathrm{~mm} \\
& \mathrm{~d}_{\mathrm{p} 2}=100 \mathrm{~mm} \\
& \mathrm{~d}_{\mathrm{p} 3}=75 \mathrm{~mm} \\
& \mathrm{~d}_{\mathrm{p} 4}=226 \mathrm{~mm}
\end{aligned}
$$

d. Kecepatan V-Belt

$$
\begin{aligned}
& \mathrm{V}_{1}=\frac{\pi \cdot d p 2 \cdot n 1}{60 \times 1000}=7,326 \mathrm{~m} / \mathrm{s} \\
& \mathrm{V}_{2}=\frac{\pi \cdot d p 4 \cdot n 2}{60 \times 1000}=12,418 \mathrm{~m} / \mathrm{s}
\end{aligned}
$$

\subsection{Baut}

Dalam perancangan mesin pengiris singkong baut yang digunakan untuk mengikat pisau pengiris, perancang menggunakan baut M14 dengan beban $\mathrm{W}=400 \mathrm{~kg}$. Waktu koreksi yang dibutuhkan 1.2, $\mathrm{d}_{1}$ $11,835 \mathrm{~mm}, \mathrm{Sf}=6, \mathrm{fc}=1.2, \sigma_{\mathrm{B}}=42 \mathrm{~kg} / \mathrm{mm}^{2}$. Adapun $\mathrm{W}=$ Beban tarik aksial pada baut, $\mathrm{Sf}=$ Faktor keamanan, $\sigma_{\mathrm{B}}=$ Kekuatan tarik, $\mathrm{d}_{1}=$ Diameter inti baut M14, perhitungan yang didapat.

a. Tegangan yang diijinkan

$$
\begin{aligned}
\sigma_{\mathrm{a}} & =\frac{\sigma b}{s f} \\
& =7 \mathrm{~kg} / \mathrm{mm}^{2}
\end{aligned}
$$

b. Beban tarik aksial

$$
\begin{aligned}
\sigma_{\mathrm{t}} & =\frac{w}{A}=\frac{w}{\left(\frac{\pi}{4}\right)(0,8 d)^{2}} \leq \sigma_{\mathrm{a}} \\
& =5.7 \mathrm{~kg} / \mathrm{mm}^{2} \leq \sigma_{\mathrm{a}}
\end{aligned}
$$

c. Diameter inti

$$
\begin{aligned}
& \mathrm{d}_{1 \geq \sqrt{\frac{2 w}{\sigma \mathrm{a}}}} \\
& \mathrm{d}_{1 \geq 10,690}
\end{aligned}
$$


d. Dipilih ulir metris kasar

$\mathrm{d}_{1}=11,835 \mathrm{~mm} \geq 10.690, \mathrm{~d}=14 \mathrm{~mm} \mathrm{p}=2 \mathrm{~mm}$

e. Jumlah lilitan

$$
\mathrm{z}=\frac{w}{\pi d_{2} h q_{\mathrm{a}}}=3.1
$$

Tabel 2. Tekanan di permukaan pada ulir.

\begin{tabular}{|c|c|c|c|}
\hline \multicolumn{2}{|r|}{ Bahan } & \multicolumn{2}{|c|}{$\begin{array}{l}\text { Tekanan permukaan yang diizinkan qa } \\
\qquad\left(\mathrm{kg} / \mathrm{mm}^{2}\right)\end{array}$} \\
\hline Ulir luar & Ulir dalam & Untuk pengikat & Untuk penggerak \\
\hline Baja liat & Baja liat atau perunggu & 3 & 1 \\
\hline Baja keras & Baja liat atau perunggu & 4 & 1,3 \\
\hline Baja keras & Besi cor & 1,5 & 0,5 \\
\hline
\end{tabular}

f. Tekanan kontak pada permukaan ulir

$$
\mathrm{q}=\frac{w}{\pi d_{2} h z} \leq \mathrm{q}_{\mathrm{a}}=2,987 \approx 3\left(\mathrm{~kg} / \mathrm{mm}^{2}\right) \approx \text { baik }
$$

g. Tinggi kaitan mur

$$
\mathrm{H}=\mathrm{z} \cdot \mathrm{p}=6.2 \mathrm{~mm}
$$

h. Gaya W memiliki tegangan geser pada luas permukaan silinder ( $\pi d 1 \mathrm{kpz})$ dimana k.p memiliki tebal ulir luar dan besar tegangan geser untuk ulir $\mathrm{K} \approx 0.84$ dan $j \approx 0.75$ maka di dapat.

$$
\tau_{\mathrm{b}}=\frac{w}{\pi d 1 \mathrm{kpz}}=2.07\left(\mathrm{~kg} / \mathrm{mm}^{2}\right)
$$

i. Tebal ulir pada mur

$$
\tau_{\mathrm{n}}=\frac{w}{\pi D j p z}=2,066\left(\mathrm{~kg} / \mathrm{mm}^{2}\right)
$$

\subsection{Pegas}

Pegas ulir dapat menerima beban maksimum W $100 \mathrm{~kg}$. Dengan defleksi antara 18-20 mm, panjang pegas $350 \mathrm{~mm}$,diameter lilitan adalah $35 \mathrm{~mm}$ dan diameter kawat $4 \mathrm{~mm}$, dalam perhitungan modulus geser $8000 \mathrm{~kg} / \mathrm{cm}, \mathrm{D}=32 \mathrm{~mm}$. Adapun $\mathrm{W}=$ Beban maksimum $(\mathrm{kg}), \mathrm{d}=$ Diameter kawat $(\mathrm{mm}), \delta=$ Lendutan $(\mathrm{mm}), \mathrm{G}=$ Modulus geser, $\mathrm{D}=$ Diameter lilitan rata rata $(\mathrm{mm})$, didalam perhitungan pegas ulir.

A. Pertimbangan atau persyaratan kerja

$$
\text { Indek Pegas }(\mathrm{C})=\frac{D}{d}=8 \mathrm{~mm}
$$

B. Momen puntir

$$
\mathrm{T}=(\mathrm{D} / 2) \cdot \mathrm{W}=1600(\mathrm{~kg} \cdot \mathrm{mm})
$$

C. Faktor tegangan Walk ( K) 
$\mathrm{K}=\frac{4 c-1}{4 c-4}+\frac{0,615}{c}=1.18$

D. Tahanan puntir kawat

$$
\begin{aligned}
Z_{p} & =(\pi / 16) d^{3} \\
& =12.56
\end{aligned}
$$

E. Tegangan geser

$$
\begin{aligned}
\tau & =\mathrm{K} \frac{8 D W_{1}}{\pi d_{3}} \\
& =76.9 \mathrm{~kg} / \mathrm{mm}^{2}
\end{aligned}
$$

F. Jumlah lilitan yang bekerja

$$
\begin{aligned}
& \delta=\frac{8 n D^{3} W_{1}}{d^{4} G} \\
& =\frac{100,000000}{26214400}=3,8
\end{aligned}
$$

G. Lendutan total

\begin{tabular}{|c|c|c|c|c|}
\hline No & Fitur & Dimensi & Bahan & Keterangan \\
\hline 1 & Poros & $\begin{aligned} \text { Diameter } & =21 \mathrm{~mm} \\
\text { Panjang } & =310 \mathrm{~mm}\end{aligned}$ & Baja ST 37 & Dibeli \\
\hline 2 & Pulley pada poros piringan & Diameter $=226 \mathrm{~mm}$ & Alumunium & Dibeli \\
\hline 3 & Pulley Pada motor listrik & Diameter $=75$ & Alumunium & Dibeli \\
\hline 4 & Pulley pada poros tengah & Diameter $=100 \mathrm{~mm}$ & Alumunium & Dibeli \\
\hline 5 & Baut & M 14 & ST 37 & Dibeli \\
\hline 6 & Bantalan & $\begin{array}{l}\text { Diameter luar }=50 \mathrm{~mm} \\
\text { Diameter dalam }=21 \mathrm{~mm}\end{array}$ & Perunggu & Dibeli \\
\hline 7 & Rangka & Profil Kotak Profil L & ST 37 & Dibeli \\
\hline 8 & Pegas & $\begin{array}{c}\text { Panjang }=350 \mathrm{~mm} \\
\text { Diameter }=4 \mathrm{~mm}\end{array}$ & SUP & Dibeli \\
\hline
\end{tabular}

$$
\delta \mathrm{t}=\delta \frac{3,5}{n}=18.4 \mathrm{~mm} \rightarrow(18-20 \mathrm{~mm}) \text { baik }
$$

H. Konstanta pegas

$$
\begin{aligned}
& \mathrm{W}_{1}=\mathrm{k} \quad \delta \mathrm{t} \\
& k=\frac{W^{1}}{\delta \mathrm{t}}=5.43 \mathrm{~kg} / \mathrm{mm}
\end{aligned}
$$

Dari hasil perancangan dengan gambar dan perhitungan sebelumnya maka diperoleh data - data.

Tabel 3. Ringkasan hasil rancangan 


\subsection{Analisis Hasil Rancangan}

\section{A. Kekuatan poros}

Dari tabel 3 dijelaskan bahwa dimensi poros memiliki diameter $21 \mathrm{~mm}$ dengan panjang $310 \mathrm{~mm}$. Tegangan geser yang diijinkan $3 \mathrm{~kg} / \mathrm{mm}^{2}$ dan torsi yang dihasilkan adalah $1500 \mathrm{~kg} / \mathrm{mm}^{2}$ sehingga tegangan geser yang timbul diperoleh $0,826 \mathrm{~kg} / \mathrm{mm}^{2}$ jadi dapat dikatakan bahwa konstruksi aman karena tegangan geser timbul $\tau g>\tau$

B. Sistem transmisi puli dan sabuk

Sistem transmisi pada mesin pengiris singkong ini menggunakan puli dengan putaran motor 1400 rpm, diameter puli penggerak adalah $75 \mathrm{~mm}$. Puli pada poros tengah terdapat 2 buah masing - masing $75 \mathrm{~mm}$ dan $100 \mathrm{~mm}$ sedangkan puli penggerak pada poros tempat dudukan pisau berdiameter $250 \mathrm{~mm}$. Bahan puli yang memiliki sifat yang kuat dan ringan.

\section{Baut dan Mur}

Untuk menyambung kedua komponen pada motor listrik, dudukan bearing, mengikat pisau pada dudukan pisau pengiris singkong, dan sebagai pengikat pendorong singkong. Baut ini dipergunakan pada mesin pemotong singkong menggunakan baut M14 sebanyak 20 buah baut, yang terbuat dari baja ST 37 dengan tegangan yang diijinkan $7 \mathrm{~kg} / \mathrm{mm}^{2}$ dan beban tarik aksial sebesar $5,7 \mathrm{~kg} / \mathrm{mm}^{2}$ baut M14 sangat cocok digunakan untuk mesin pengiris singkong karena tegangang yang diijinkan lebih besar dari beban tarik aksial.

D. Bantalan pada poros

Bantalan yang digunakan pada mesin pengiris singkong ini adalah bantalan berbentuk bola, yang dipergunakan pada dudukan bantalan sebanyak 4 buah bantalan merk Pillow Block Bearing, UC 204 diameter luar 50mm, dan diameter dalam $21 \mathrm{~mm}$.

Supaya putaran pada poros dapat berputar dengan lancar maka yang perlu diperhatikan oleh operator mesin pengiris singkong itu sendiri adalah sistem pelumasan dengan menggunakan oli, karena oli merupakan sistem pelumasan yang cukup baik.

\section{E. Rangka}

Rangka mesin pengiris singkong berfungsi sebagai dudukan pada komponen mesin pengiris singkong yang terbuat dari profil $U$ dan kotak dengan panjang $65 \mathrm{~cm}$ dan lebar $60 \mathrm{~cm}$ yang terbuat dari baja ST37. Cara penyambungan rangka pada mesin pengiris singkong ini perancang menggunakan proses las karena proses las merupakan proses yang tepat untuk penyambungan.

\section{F. Pegas}

Pegas merupakan benda elastis yang digunakan untuk menyimpan energy mekanis. Pegas untuk pengiris singkong ini terbuat dari kawat baja dengan lambang SUP dengan diameter kawat $4 \mathrm{~mm}$ panjang 
$350 \mathrm{~mm}$ yang berfungsi sebagai tenaga pendorong pada dudukan pendorong singkong, konstanta pegas pada mesin pengiris singkong ini adalah sebesar $5.43 \mathrm{~kg} / \mathrm{mm}$, lendutan $18-20 \mathrm{~mm}$ dan lendutan total adalah sebesar $18.2 \mathrm{~mm}$. pegas ini sangat baik digunakan karena lendutan total masih di kisaran angka pada lendutan.

\section{G. Penguji Alat}

Uji kinerja mesin perlu dilakukan untuk mengetahui hasil kinerja mesin yang telah dibuat. Selain dapat mengetahui kualitas hasil kinerja mesin, uji kinerja diharapkan dapat mengetahui kekurangankekurangan pada mesin yang telah dibuat. Mesin pengiris singkong ini dilengkapi dengan pendorong singkong pada dudukan pisau dan mesin pengiris ini mampu mengiris singkong dengan kapasitas 90 $\mathrm{kg} / \mathrm{jam}$ dengan hasil irisan yang hampir seragam.

\section{SIMPULAN}

Dari penelitian yang telah dilakukan, mesin yang dirancang telah berfungsi dengan baik terbukti dengan hasil irisan yang seragam. Kapasitas produksi mesin pengiris singkong hasil rancangan adalah $90 \mathrm{Kg} / \mathrm{jam}$. Mesin ini menggunakan pisau dengan 4 buah mata pisau, tebal pisau $1 \mathrm{~mm}$, panjang $40 \mathrm{~mm}$ dan lebar $70 \mathrm{~mm}$. Motor yang digunakan dalam mesin pengiris singkong ini merupakan motor listrik dengan kapasitas daya $1 / 2 \mathrm{Hp}$, putaran $n=1400 \mathrm{rpm}$ Tegangan 110/220 volt. Poros yang digunakan memiliki diameter $21 \mathrm{~mm}$ dengan panjang 310mm bahan poros dari bahan ST 37 dengan kekuatan tarik $\sigma_{\mathrm{B}}=37 \mathrm{~kg} / \mathrm{mm}^{2}$ dan didapat tegangan geser $\tau_{g}=3 \mathrm{~kg} / \mathrm{mm}^{2}$. Sistem penggerak motor listrik yang dipergunakan $560 \mathrm{rpm}$, dengan menggunakan komponen 4 puli yang dihubungkan melalui $V$-belt A 47 dan A 48 pada poros pemutar pulley tengah dan dudukan pisau.

\section{DAFTAR PUSTAKA}

M. Abdul Mukhyi, "PENERAPAN TEKNOLOGI SISTEM INFORMASI DAN TEKNOLOGI TEPAT GUNA PADA USAHA KECIL MENENGAH,” Semin. Ilm. Nas. Komput. dan Sist. Intelijen Audit. Univ. Gunadarma, 2008.

[2] F. Wulandari, "UJI KADAR PROTEIN TAPE SINGKONG (Manihot utilissima) DENGAN PENAMBAHAN SARI BUAH NANAS (Ananas comosus),” Skripsi, 2008.

[3] A. P. Cardoso et al., "Processing of cassava roots to remove cyanogens," J. Food Compos. Anal., 2005, doi: 10.1016/j.jfca.2004.04.002.

[4] "Potential utilization of cassava pulp for ethanol production in Indonesia," Sci. Res. Essays, 2012, doi: 10.5897/SREX11.022.

[5] S. Askar, "Daun Singkong dan Pemanfaatannya Terutama sebagai Pakan Tambahan," Wartazoa, 1996.

[6] S. Prabawati, N. Richana, and Suismono, "Inovasi Pengolahan Singkong Meningkatkan Pendapatan dan Diversifikasi Pangan,” Sinar Tani Ed. 4-10 Mei 2011 No.3404 Tahun XLI, 2011.

[7] K. Rangkuti, M. Ainul, and A. D. Putri, “Analisis nilai tambah keripik singkong pada Kelompok 
Usaha Keluarga (KUK) Desa Sipare-Pare,” Agrium, 2015.

[8] S. Herawati, G. Irawan, and M. Mujiono, "Pelatihan Membuat Keripik Singkong dan Talas di Desa Brongkal, Kecamatan Pagelaran Kabupaten Malang," JAPI (Jurnal Akses Pengabdi. Indones., 2019, doi: 10.33366/japi.v4i1.1225.

[9] H. La Kamisi, “Analisis usaha dan nilai tambah agroindustri kerupuk singkong," Agrikan J. Ilm. Agribisnis dan Perikan., 2011, doi: 10.29239/j.agrikan.4.2.82-87.

[10] E. Surahman, A. Satrio, and H. Sofyan, "Kajian Teori Dalam Penelitian," JKTP J. Kaji. Teknol. Pendidik., 2020, doi: 10.17977/um038v3i12019p049. 